\title{
DETERMINANTS OF THE ENERGY SAVING CONSTRUCTION QUALITY IN THE GREEN DESIGN
}

doi: 10.2478/cqpi-2019-0024

Date of submission of the article to the Editor: 14/04/2019

Date of acceptance of the article by the Editor: 28/05/2019

Renata Stasiak-Betlejewska ${ }^{1}$ - orcid id: 0000-0001-8713-237X

Eva Nedeliaková ${ }^{2}$ - orcid id: 0000-0001-5588-0939

${ }^{1}$ Czestochowa University of Technology, Poland

'University of Žilina, Slovakia

\begin{abstract}
Crucial element of the contemporary construction development trend is compatibility of the building design with client and architecture trends and sustainability strategy. The environmental certification systems for buildings such as LEED, BREEAM and WELL apply a lot of attention to providing users with a healthy housing environment. The criteria of these systems include many practical recommendations that buildings should meet on design, construction and use stage. These requirements can be a signpost, even for buildings and offices that do not aspire to obtain a certificate. The aim of the paper is to analyze and identify determinants of the energy-saving construction quality in the context of the green design.
\end{abstract}

Keywords: construction, sustainable construction, green design, quality

\section{INTRODUCTION}

Contemporary construction development is based on the sustainable development concept that is one of the main challenges faced by the construction industry, which has acquired global attention. Sustainable construction performance is considered in the construction project during its life cycle. There are approximately 53 sustainable factors (economic, social, and environmental sustainable factors) that were identified through extensive literature review and confirmed by experts' interviews and a pilot study. These factors are classified in relation to the project life cycle phases; inception phase, design phase, construction phase, operation phase, and demolition phase (Enshassi, et al. 2016).

Sustainable construction development is referred to fulfillment of human needs through simultaneous socio-economic and technological progress and conservation of the earth's natural systems (Khalfan, et al. 2002). In the opinion of the World Commission on the Environment and Development (WCED) the sustainable performance of a construction project should meet the needs of the present without compromising the ability of the future generations (WCED (1987), what is related to construction activities having various on the environment (Wang et al. 2011; Kaatz et al. 2005). The main effect of the construction quality design has influence of the following factors: the energy 
consumption, dust and gas emission, noise pollution and waste generation, water discharge, misuse of water resources, land misuse and pollution, and consumption of non-renewable natural resources (Shen et al. 2007; Agarwal, 2011).

An essential approach of contemporary construction development trend is compatibility of the building design with client and architecture trends and sustainability strategy. It is related to the interpretation of quality of life that can perceived by perspective of the following goals (Pant et al. 2011):

- environment: reduces water use, reduce net land disturbance, and reduce net emissions;

- social: improve equal employment opportunities, improve contribution to community capacity building, reduce impact on heritage; and

- economic: optimize long-term economic value.

It is estimated that by 2056, global economic activity will have increased fivefold, global population will have increased by over $50 \%$, global energy consumption will have increased nearly threefold, and global manufacturing activity will have increased at least threefold (Matthews, 2000).

Building envelope refers to an enclosure of a built environment, which comprises of walls, doors, windows, roof, skylights, and other openings for light and ventilation. Building envelope as the totality of (building) elements made up of components which separate the indoor environment of the building from the outdoor environment (Oral et al.,2004). In the contemporary construction design suitable with the sustainable construction, design features of an envelope strongly affect the visual and thermal comfort of the occupants, as well as energy consumption in the buildings (Kumar and Raheja, 2016).

The most often met term in the sustainable construction is term energy efficiency that is connected with reduction of the amount of energy required to provide comfortable indoor spaces in the buildings. It can be green or energy efficient according to the building energy certification, but not sustainable (Dempsey and Bramley, 2012). According to the energy saving priority must work efficiently for a long period keeping comfort, function, usability, durability of the space and material what is related to the users who accept the indoor conditions in the sustainable buildings. This concept is an integrative and holistic process of maintaining a dynamic balance between the needs and demands of people for equity, prosperity and quality of life (Plesis, 2003). In accordance to the sustainable construction concept and contemporary problem of te energy efficiency in architectural design targets for the European Community for 2020, expressed in the so-called "Green Paper Energy Efficiency" are as follows (PTCE 2005; Kamionka, 2017):

- achieving potential savings in buildings in terms of energy used for heating, air conditioning, hot water and lighting at $22 \%$,

- achieving potential savings in buildings in terms of energy used for heating, air conditioning, hot water and lighting at $22 \%$,

- doubling the share of renewable energy from $6 \%$ to $12 \%$ in the overall consumption of electricity,

- increasing the share of green electricity from $14 \%$ to $22 \%$ in the total consumption of energy.

Fulfillment of the energy efficiency targets are connected with green building rating systems such as: Building Research Establishment's Environmental Assessment 
Method (BREEAM), Leadership in Energy and Environmental Design (LEED) rating system for new construction. LEED and BREEAM certificates are effective tools for assessing the sustainability of a building during its design, construction and operational stages. Solutions aimed at increasing energy efficiency in office buildings should ensure the highest possible indoor air quality while maintaining the most cost-effective energy consumption levels. Sustainable development principles should balance energy costs with the comfort and health of the user. That's why the main conditio of sucessfull close collaboration among all stakeholders involved in a building's life cycle from the design stage - investor, tenant, architect, engineer, monitoring firm and property manager will guarantee an energy-efficient building.

The main goal of the paper is identification and analyss of determinants of the energysaving construction quality in the context of the green design.

\section{ENERGY EFFICIENCY BUILDINGS DETERMINANTS}

One of the study based on energy consumption data was aimed at assessment of the electricity and heat usage in office buildings in Poland. The study covered 20 office buildings. The surveyed facilities were selected based on data provided by the project partners and technical capabilities of the developed methodology. Analysed building have sustainable development building certicates (LEED CS certificate, BREEAM certificate; BREAM NC). The assessment criteria included (Austyniak et al. 2017):

- energy consumption by a given user depending on technological processes,

- comparison of the energy consumption of different tenants in different buildings,

- estimation of energy savings achieved by buildings holding a green certificate,

- comparison of the energy usage of buildings in operation to their predicted energy usage and energy performance,

- estimation of energy savings in recently completed buildings,

- evaluation of the efficacy of activities undertaken by the investor (project) and the property manager (operation) aimed at optimising energy usage; and

- assessment of the building's durability in terms of its energy performance.

Mentioned above analysis of the building's energy cost savings in the context of the age of the building and its certificate demonstrated that:

- differences between the energy savings of the buildings were so small that it was difficult to determine how the certificate type and/or certificate degree affected the energy savings of the building;

- buildings with "full" certificates, which denote the top level of energy-efficient design, materials and construction, produced a higher average cost savings, $26 \%$, than the average of $20 \%$ for the other certificate types included in the survey (BREEAM NC, LEED CS);

- buildings with "In Use" certificates (BREEAM In Use) offered superior cost savings through energy efficiency, with one exception, compared with buildings of the same age. This may be the effect of the requirements for the certificate, which are intended to ensure the energy-efficient management of the building. However, the differences were so small that it was difficult to show this relationship clearly;

- buildings without a certificate offered lower cost savings relative to certified buildings, but they still showed a modest amount of cost savings, demonstrating to their owners that these buildings were aging to a manageable extent in terms of energy consumption. 
The key findings confirm that the investor has a significant effect on the energy performance of a building what result from the energy performance of building.

Energy Performance of Building Directive defined elements of the energy efficiency certificates elements in the following definitions (Directive 2010/31/EU):

1. "Building" means a roofed construction having walls, for which energy is used to condition the indoor climate;

2. "nearly zero-energy building" means a building that has a very high energy performance. The nearly zero or very low amount of energy required should be covered to a very significant extent by energy from renewable sources, including energy from renewable sources produced on-site or nearby;

3. "Technical building system" means technical equipment for the heating, cooling, ventilation, hot water, lighting or for a combination thereof, of a building or building unit;

4. "Energy performance of a building" means the calculated or measured amount of energy needed to meet the energy demand associated with a typical use of the building, which includes, among others, energy used for heating, cooling, ventilation, hot water and lighting;

5. "Energy from renewable sources" means energy from non-fossil renewable energy sources, namely wind, solar, solar, aerothermal, geothermal, hydrothermal and ocean energy, hydropower, biomass, gas from landfills, sewage treatment plants and from biological sources (biogas);

6. "Building envelope" means the integrated elements of a building which separate its interior from the outdoor environment;

7. "Building unit' means a section, floor or apartment within a building which is designed or altered to be used separately;

8. "Building element" means a technical building system or an element of the building envelope;

9. "Major renovation" means the renovation of a building where:

a) the total cost of the renovation relating to the building envelope or the technical building systems is higher than $25 \%$ of the value of the building, excluding the value of the land upon which the building is situated; or

b) more than $25 \%$ of the surface of the building envelope undergoes renovation;

10. "European standard" means a standard adopted by the European Committee for Standardisation, the European Committee for Electrotechnical Standardisation or the European Telecommunications Standards Institute and made available for public use;

11. "Energy performance certificate" means a certificate recognised by a Member State or by a legal person designated by it, which indicates the energy performance of a building or building unit, calculated according to a methodology adopted in accordance with adoption of a methodology for calculating the energy performance of buildings;

12. "Cogeneration" means simultaneous generation in one process of thermal energy and electrical and/or mechanical energy;

13. "Cost-optimal level" means the energy performance level which leads to the lowest cost during the estimated economic lifecycle, where:

a) the lowest cost is determined taking into account energy-related investment costs, maintenance and operating costs (including energy costs and savings, 
the category of building concerned, earnings from energy produced), where applicable, and disposal costs, where applicable; and

b) the estimated economic lifecycle is determined by each Member State. It refers to the remaining estimated economic lifecycle of a building where energy performance requirements are set for the building as a whole, or to the estimated economic lifecycle of a building element where energy performance requirements are set for building elements.

The cost-optimal level shall lie within the range of performance levels where the cost benefit analysis calculated over the estimated economic lifecycle is positive.

14. "Air-conditioning system" means a combination of the components required to provide a form of indoor air treatment, by which temperature is controlled or can be lowered;

15. "Heat pump" means a machine, a device or installation that transfers heat from natural surroundings such as air, water or ground to buildings or industrial applications by reversing the natural flow of heat such that it flows from a lower to a higher temperature. For reversible heat pumps, it may also move heat from the building to the natural surroundings;

16. "District heating" or "district cooling" means the distribution of thermal energy in the form of steam, hot water or chilled liquids, from a central source of production through a network to multiple buildings or sites, for the use of space or process heating or cooling.

Theres is also a very important issue of the building's energy quality that is characterized by indicators (usually marked with the letter "E" with the relevant indices) whose value is obtained by dividing the cubic capacity or floor area of considered building, net energy, gross energy (supplied) or primary energy necessary to provide the required level of heating, cooling, ventilation, water heating and lighting in the building, at the material time (usually a time period covers the year). On this basis it is possible to formulate the assessment of the quality of a building's energy by assignment energy class A, B, C, D, E, F, G (similarly as for household appliances).

\section{CONCLUSION}

Sustainable construction is considered nowadays as the primary axis of the construction designing since sustainability building practices are aimed at balancing economical, social and environmental performance of the buildings.

Growing awarenesss of the customers on the environmental protection turn designers and builders attention towards new technologies and solutions in the design and production processes with minimizing impact on the environment. Understanding the sustainable construction and energy saving standards are crucial for the effective solutions of the building meeting European Directive standards.

\section{REFERENCES}

Agarwal, K. 2011. Verifying survey items for construct validity: a two phase sorting procedure for questionnaire design in information behavior research. In proceedings of the American Society for Information Science and Technology, 48 (1), 1-8.

Augustyniak, T., Bartkiewicz, P., Iliński, R., 2017. Energy Consumption in Office Buildings: a Comparative Study. Skanska, Cushman \& Wakefield, Go4Energy. Warsaw. 
PTCE, Biuletyn Polskiego Towarzystwa Certyfikacji Energii. 2005. Poznań, 3, 1-2.

Dempsey, N, and Bramley, G. (2012). The Social Dimension of Sustainable Development: Defining Urban Social Sustainability. Sustainable Development, 19: 289-300.

Directive 2010/31/EU of the European Parliament and of the Council of 19 May 2010 on the energy performance of buildings. Official Journal of the European Union. 18.6.2010

Enshassi, A., Kochendoerfer, B., Al Ghoul, H., 2016. Factors Affecting Sustainable Performance of Construction Projects during Project Life Cycle Phases. International Journal of Sustainable Construction Engineering \& Technology, 7 (1), Universiti Tun Hussein Onn Malaysia (UTHM) and Concrete Society of Malaysia (CSM)

Kaatz, E.; Root, B.; and Bowen, P., 2005. Broadening project participation through a modified building sustainability assessment. Journal of Civil Engineering and Management, 33 (5), 441-454. DOI: 10.1080/09613210500219113

Kamionka, L., 2017. Energy aspect in sustainable design using the example of multicriteria methods of building evaluation, Structure, 2.

Khalfan, M., Bouchlaghem, D., Anumba, C., Carrillo, P. 2002. A framework for managing sustainability knowledge- the $C$-sand approach. In proceedings of ESm@rt conference, Salford, U.K.

Kumar, G., Raheja, G., 2016. Design Determinants of Building Envelope for Sustainable Built Environment: A Review. International Journal of built environment and sustainability, Faculty of Built Environment, Universiti Teknologi Malaysia, DOI: DOI: 10.11113/ijbes.v3.n2.127

Matthews, E.; Amann, C.; Fischer-Kowalski, M.; Huttler, W.; Kleijn, R.; Moriguchi, Y.; Ottke, C.; Rodenburg, E.; Rogich, D.; Schandl, H.; Schutz, H.; van der Voet, E.; Weisz, H., 2000. The Weight of Nations: Material Outflows from Industrial Economies; World Resources Institute: Washington, DC, USA, Available online: http://pdf.wri.org/weight_of_nations.p (accessed on 24 May 2009).

Oral, G. K, Yener, A. K, and Bayazit, N. T. 2004. Building Envelope Design with the Objective to Ensure Thermal, Visual and Acoustic Comfort Conditions. Building and Environment, 39: $281-287$.

Pant, D.; Singh, A.; Van Bogaert, G.; Gallego, A.; Diels, L.; and Vanbroekhoven, K., 2011. An introduction to the life cycle assessment (LCA) of bio electrochemical systems (BES) for sustainable energy and product generation: relevance and key aspects. Renewable and Sustainable Energy Reviews, 15 (2), 1305-1313. DOI: 10.1016/j.rser.2010.10.005

Plessis, C. 2003. Analyzing the sustainability of human settlements in South Africa: Challenges and methods. CSIR Building and Construction Technology, Pretoria.

Shen, L.; Hao L.; Tam, V.; and Yao, H., 2007. A checklist for assessing SP of construction projects. Journal of Civil Engineering and Management, 13 (4), 273281. DOI: $10.1080 / 13923730.2007 .9636447$

Wang, Z.; Calderon, M.; and Lu, Y., 2011. Lifecycle assessment of the economic, environmental and energy performance of biodiesel in China. Biomass and Bioenergy, 35, 2893-2902.

World Commission on Environment and Development- WCED (1987). The Brundtland Report,-pp.35.-Available_at:

http://web.env.auckland.ac.nz/courses/geog320/resources/pdf/sustainability/Snedd on_et-al_2006.pdf [Accessed on 3/4/13]. 